\title{
Revealing Hidden Innovation: Patterns of External Innovation Investment in Australian Businesses \\ Kieran O’Brien
}

\author{
"Invention, using the term most broadly, and" \\ imitation, are the two legs, so to call them, on \\ which the human race historically has walked. \\ William James (1842-1910) \\ Philosopher, psychologist, and physician
}

\begin{abstract}
Recent theory and literature suggests that many businesses now innovate based on the adoption and modification of knowledge, technology, and innovations sourced externally rather than developed in-house. Yet, little is known about the value and economic impact of expenditures on outsourced innovation activities, which are often referred to as "hidden innovation" by many scholars. The issue is due largely to a lack of consistent measurement, available data, and analyses of expenditures on hidden innovation. In contrast, there is a long history of cross-country data collection on in-house research and development (R\&D) activities and costs, and much research focuses on innovations involving in-house R\&D effort. This study reviews results from a survey aimed at collecting new economy-wide data on external innovation investments in Australia. The results estimate total unmeasured or "hidden" investment in external innovation activities by Australian businesses at $\$ 3.5$ to $\$ 4$ billion in 2014, an amount large enough to stimulate important economic activity and warrant future research. This article discusses the implications of these results for policy, business strategy, and future research on innovation.
\end{abstract}

\section{Introduction}

Over the past decades, empirical innovation research has widened in scope to incorporate a broad definition of innovation that includes the business introduction of new or improved products, processes, organizational, or marketing methods (OECD, 2005). However, government policies and empirical studies of business innovation investments invariably focus on in-house research and development $(\mathrm{R} \& \mathrm{D})$ expenditures as the main type of investment (Damanpour \& Aravind, 2012; Demirel \& Mazzucato, 2012).

In-house $\mathrm{R} \& \mathrm{D}$ expenditures cover the internal production of new knowledge and technology by businesses for the development of product and process innovations. However, for many businesses, the development and implementation of innovations involves the adoption of knowledge and technology produced by other businesses or organizations. Organizational or market- ing innovations, for example, may require little or no inhouse R\&D activity or investment, but expenditures on different types of activities such as system design and testing, staff training, or the purchase of technology licenses, equipment, or consulting expertise. Similarly, not all product and process innovations require $R \& D$ as an input (Barge-Gil et al., 2011). Yet, despite non-R\&D modes of innovation being dominant in many large industries such as services or traditional low-tech sectors (Hansen \& Serin, 1997; Hirsch-Kreinsen, 2008), much of the policy and research focus remains on the production of new technology via R\&D, rather than its effective absorption, integration, modification, and use (EBRD, 2014). To date, R\&D support policies remain the most popular innovation policies across the OECD countries (OECD, 2006). In Australia, for instance, Government expenditure on business R\&D support programs in 2015-16 accounted for approximately $\$ 2.9$ billion and $30 \%$ of the entire science, technology and innovation budget (DIIS, 2015). 


\section{Patterns of External Innovation Investment in Australian Businesses}

\section{Kieran O'Brien}

Non-R\&D-based innovation investment is typically understudied due to a lack of consistent or adequate measurement, and limitations with existing data (Kleinknecht et al., 2002). Previous research identifies this as a problem of "hidden innovation" (Barrett et al., 2007; Harris \& Halkett, 2007; Miles \& Green, 2008). Harris and Halkett (2007) give the example of the oil and gas sector in the United Kingdom, where innovation activity can involve billion dollar investments that are not reflected in industry innovation metrics. This is because innovation projects in this sector often draw on $R \& D$ activity dispersed across a variety of actors and locations, and innovative exploration activities are not counted as R\&D (Harris \& Halkett, 2007). Similarly, Barrett and colleagues (2007) cite the construction sector as an industry where much innovation activity is hidden at the project level or in general organizational development. In short, the main problem is that, for a large proportion of businesses that make up the bulk of most advanced economies, hidden innovation involves investments that are currently not measured or understood very well, neglected in empirical studies, and often receive relatively little policy attention.

This hidden innovation problem provides the rationale for this article, which seeks to address the need for better measurement and understanding of the value of firm investments in external innovation development activities, drawing on new evidence from a 2015 survey of 1600 randomly selected Australian businesses. The following section provides the context for this study by briefly discussing some historical background behind the issue of hidden innovation and the measurement of business innovation investments. The article then examines the patterns and value of external innovation investments in Australian firms. The concluding discussion considers the implications of the survey results. Throughout the article, the terms "hidden innovation" and "external innovation investments" are used interchangeably.

\section{Measurement of Innovation Investments and Hidden Innovation}

Much of the traditional economic literature on innovation has focused on high-tech innovation driven by internal R\&D (Santamaria et al., 2009). This is often seen as a hangover from linear or science-push theories of innovation that view scientific discovery as the starting point of any innovation (Godin, 2000). These views were dominant around the first half of the 20th century when manufacturing accounted for a much larger share of activity in the western economies, and innovation often began in the R\&D departments of large industrial firms.

However, the past few decades have seen a rapid decline in the share of manufacturing in the advanced economies while at the same time, the size and economic importance of service sectors has increased. Services firms now make up the bulk of businesses (over $70 \%$ ) in most developed economies (OECD, 2013). For businesses in the services industries, innovation is often characterized by new design processes or marketing techniques, adopted and modified information technologies, service customization, and knowledge sourced from customers and embodied in routines, procedures, and organizational methods (Gallouj \& Weinstein, 1997; Sundbo, 1997). Such innovation can often involve little or no in-house R\&D activity or investment, and remains largely undetected or "hidden" in the long tradition of $\mathrm{R} \& \mathrm{D}$ and innovation statistics (Barrett et al., 2007; Harris \& Halket, 2007; Miles, 2005). This is because many productivity enhancing innovation investments by services firms involve technology acquisition, integration, or modification rather than in-house production through $R \& D$. An example is a small to medium-sized accounting firm that implements a new, more efficient back-office processing platform based on a cloud computing solution purchased from a software provider.

A similar situation is found in traditional or "low-tech" industries such as mining or agriculture. In low-tech sectors, the most common type of innovation is the introduction of new processes requiring investments in new equipment or machinery. Such innovation embodies R\&D conducted by equipment suppliers (Kirner et al., 2009; von Tunzelmann \& Acha, 2005) and often involves no direct in-house $R \& D$ by the innovating business. An example is the mechanization of pruning and harvesting in the wine industry - a process innovation enabled by the purchase of new machinery (Smith \& Marshall, 2007).

For many industries in modern economies then, much innovation is based on inputs purchased from technology-producing industries, and in many countries, the "high-tech" producing industries are typically much smaller contributors to the overall economic structure in terms of output and employment. In Australia, for example, high-tech manufacturing consistently accounts for less than $1 \%$ of total economic output (Arundel \& O'Brien, 2009). The entire manufacturing sector only accounted for $6.8 \%$ of output in 2015 , down from $11.3 \%$ 10 years earlier (ABS, 2015). 


\section{Patterns of External Innovation Investment in Australian Businesses}

\section{Kieran O'Brien}

Academic research has recognized these structural changes across many advanced economies and the different modes of innovation that have emerged. New theories of "open innovation" emphasize the value of innovations that are brought in from outside of the firm (as well as spun out) (Chesbrough, 2003; van de Vrande et al., 2010) or that develop from customer insights or ideas rather than in-house R\&D (von Hippel, 2005). Results from economy-wide business surveys suggest that non-R\&D innovation activities and investments are widespread in many industries and make up a large share of overall business innovation activity (Arundel et al., 2008). For example, in an early study of innovation expenditures in the Netherlands, Brouwer and Kleinknecht (1997) found that approximately half of all product and service innovation expenditure was on fixed assets for innovation, and these types of investments were higher in services industries compared to manufacturing.

Yet, despite these developments, there remains limited empirical research on the extent of investments in innovation activities apart from in-house R\&D. Equally, despite a burgeoning literature on open innovation, there is limited work on the costs of open innovation strategies (Huizingh, 2011). Key reasons for this are a lack of measurement, a lack of available data, and limitations or quality problems with existing data (Kleinknecht et al., 2002). In Australia, for example, statistics on $R \& D$ currently provide the most comprehensive source of data on business expenditures related to innovation. R\&D activity and investment is crucial to innovation, but the notion of hidden innovation suggests that we are missing much of the picture in terms of business investments in non$\mathrm{R} \& \mathrm{D}$ innovation activities. Developing new measures and data is a first step towards better understanding economic outcomes from these activities.

This article tackles the issue of hidden innovation and addresses the need for better data on innovation investments, contributing to the limited literature in this space. The focus is on understanding the size and structure of hidden innovation investments in Australia. Developing a better evidence base in this respect is crucial to understanding different types of business innovation expenditures, their impact on innovation success and economic activity, and the potential role, if any, that policy might play in stimulating, facilitating, or enabling innovation investment.

This study is motivated by the central research question: What is the magnitude of investment in external activities for innovation in Australian businesses?

\section{Research Methods}

This article uses data from a 2015 survey of the innovation activities and investments of Australian businesses. The survey covered a random sample of 1600 businesses selected from a national business register, and was part of a research project undertaken for the Australian Department of Innovation, Industry and Science (http://industry.gov.au). The survey questionnaire was administered using both mailed and online questionnaires. Of 1600 selected businesses, 359 responded, giving a response rate of $22.4 \%$. No evidence was found of non-response bias, suggesting that the results are representative of the broader population of Australian businesses. The survey questionnaire design was based on the national Business Characteristics Survey (BCS) conducted by the Australian Bureau of Statistics (ABS). Given that the BCS design is based on guidelines provided by the OECD (2005), the study results are relevant for other countries conducting innovation surveys based on the same guidelines.

The survey questions covered firm activities in the 2014 calendar year. Of all respondent firms, $77 \%$ are in services, $15 \%$ are in primary resources, and $8 \%$ are in manufacturing. As with the overall business population in Australia and many countries, the large majority of respondent businesses are SMEs: $65 \%$ have fewer than 200 employees (including 17\% with 0-4 employees) and $35 \%$ have 200 or more employees (including 10\% with 200-299 employees and $25 \%$ with 300 or more employees).

To measure the level of external innovation investment by businesses (hidden innovation), the survey questionnaire asked businesses to report their 2014 expenditure on four external innovation activities (Box 1).

\section{Survey Results}

\section{External innovation investment by activity}

Figure 1 shows the distribution of total reported external innovation investment by expenditure category for all innovative respondent firms in 2014, as calculated by summing the individual values reported across the four activities in Box 1. An "innovative firm" is defined as a firm that introduced at least one new or significantly improved product, process, organizational, or marketing method in 2014. The total amount reported was approximately $\$ 1.8$ billion. The purchase of new machinery, equipment, or technology for innovation clearly accounts for the greatest share of the total (88.3\%). Purchases of design, marketing, or training ser- 


\section{Patterns of External Innovation Investment in Australian Businesses}

\section{Kieran O'Brien}

Box 1. Survey question used to calculate total external investment by Australian businesses

During the year ended 31 December 2014, approximately how much did this business spend on the following external activities to develop, or introduce new or significantly improved goods, services, processes or marketing methods?

a. Purchase of machinery, equipment or technology (including hardware and software) with functions or capabilities that were new or significantly improved for this business $\$$

b. Purchase of research services from other businesses $\$$

c. Purchase of design, marketing or training services from other businesses $\$$

d. Purchase of licenses to use patents or other types of intellectual property owned by other businesses or organisations (exclude licenses to common software such as Microsoft Office) $\$$

vices account for $9.8 \%$ and research services and licences less than $2 \%$. Of note, though results by industry are not shown here (see Appendix A), businesses in services account for $87.3 \%$ of the total amount of investment reported, which is in line with the proportion of all responding businesses that are in services $(77 \%$ of respondent firms). Though manufacturing and primary resources industries accounted for less than $15 \%$ of total reported investment (reflecting their share of the total number of business respondents), the median external innovation investment values in these sectors were substantially higher than in services (more than three times larger in primary resources and five times larger in manufacturing).

In Table 1, total investment is broken down by firm size, showing total external investment expenditure as well as median investment expenditure for all innovative respondent firms. Businesses with 200 or more employees account for $98.2 \%$ of total investment. As expected, smaller businesses are relatively more constrained in their external innovation investments.

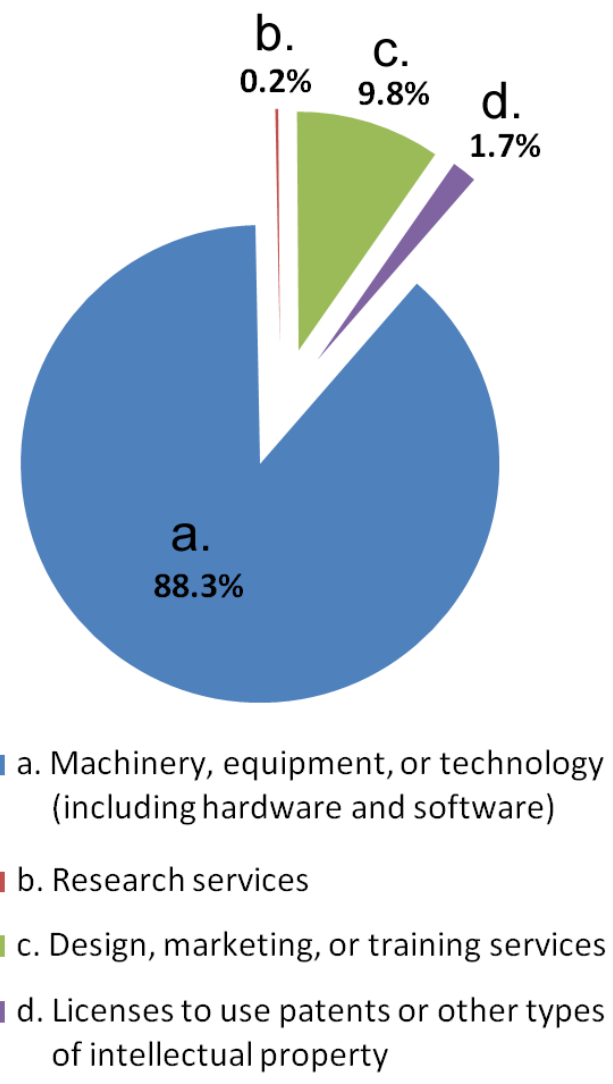

Figure 1. Distribution of total external innovation investment by expenditure category for 225 innovative Australian firms

Estimating external innovation investment for all Australian businesses

To estimate the total value of external innovation investment for all innovative Australian businesses, survey data from Table 1 is combined with national figures from the 2013-14 business survey conducted by the Australian Bureau of Statistics (ABS, 2014a). This national data provides an estimate of the total number of innovative businesses in Australia in each firm size group. (Full information on the national business register population was not available for this study, so estimating the total number of innovative Australian businesses was not possible using the survey data.)

Given the total number of innovative businesses in Australia (ABS, 2014a), we can generate an estimate of total investment for all Australia by assuming the median investment value reported in Table 1 for each innovative Australian business:

- The median value for external innovation investment (from Table 1) is multiplied by the number of innovat- 


\section{Patterns of External Innovation Investment in Australian Businesses}

\section{Kieran O'Brien}

ive firms in each size group (from the Australian Bureau of Statistics national survey) to provide an estimate of the national external investment for each size group. The median value is used because it provides a conservative estimate that is less impacted by the skewed distribution of investment expenditures in each group.

- An estimate of total external investment for all Australian businesses is then calculated by summing individual estimates for each size group. A full description of the method used to impute upper and lower bound investment figures for all Australian businesses is provided in Appendix A.

The results in Table 2 are indicative only - they do not incorporate any response bias, population weightings, nor do they feature standard errors. Despite these limitations, this approach is sufficient to build a picture of the size of hidden innovation investments in Australia and address the question motivating this study. What the figures show is that the total investment in external innovation activities by Australian businesses in 2014 is $\$ 3.5$ billion at the lower range and $\$ 4$ billion at the upper range. These amounts are certainly large enough to warrant attention. To provide some context, the latest Australian data estimates total business expenditure on $\mathrm{R} \& \mathrm{D}$ for innovation at $\$ 18.9$ billion in 2013-14 (ABS, 2014b).

\section{Conclusions and Implications}

The main objective of this article was to examine the issue of "hidden innovation" and provide an empirical picture of the nature and magnitude of hidden innovation investment in Australia. This task was approached by examining new data from a 2015 survey of the innovation investment activities of 1600 randomly selected Australian businesses.

Table 1. Total external innovation investments by employment size category

\begin{tabular}{lccccc}
\hline & $\begin{array}{c}\text { Number of } \\
\text { Respondents }\end{array}$ & Total Expenditure & $\begin{array}{c}\text { Median } \\
\text { Expenditure }\end{array}$ \\
\hline 0-4 persons & 28 & $\mathbf{1 2 . 4 \%}$ & $\$ 4,767,000$ & $0.3 \%$ & $\$ 3,500$ \\
\hline $5-19$ persons & 45 & $20.0 \%$ & $\$ 3,100,000$ & $0.2 \%$ & $\$ 7,000$ \\
\hline $20-199$ persons & 66 & $29.3 \%$ & $\$ 24,022,000$ & $1.4 \%$ & $\$ 46,500$ \\
\hline 200 or more persons & 86 & $38.2 \%$ & $\$ 1,744,218,000$ & $98.2 \%$ & $\$ 150,000$ \\
\hline All firms & $\mathbf{2 2 5}$ & $\mathbf{1 0 0 . 0 \%}$ & $\mathbf{\$ 1 , 7 7 6 , 1 0 7 , 0 0 0}$ & $\mathbf{1 0 0 \%}$ & $\$ \mathbf{3 3 , 0 0 0}$ \\
\hline
\end{tabular}

Table 2. National estimates of external innovation expenditure by employment size category

\begin{tabular}{lcc}
\hline & $\begin{array}{c}\text { Lower Range Estimate } \\
\$ \text { Millions }\end{array}$ & $\begin{array}{c}\text { Upper Range Estimate } \\
\$ \text { Millions }\end{array}$ \\
\hline $0-4$ persons & $\$ 554$ & $\$ 758$ \\
\hline $5-19$ persons & $\$ 871$ & $\$ 929$ \\
\hline $20-199$ persons & $\$ 1,637$ & $\$ 1,835$ \\
\hline 200 or more persons & $\$ 443$ & $\$ 416$ \\
\hline Total & $\mathbf{\$ 3 , 5 0 5}$ & $\mathbf{\$ 3 , 9 3 8}$ \\
\hline
\end{tabular}




\section{Patterns of External Innovation Investment in Australian Businesses}

\section{Kieran O'Brien}

The results estimate total "hidden" investment in external innovation activities by Australian businesses at $\$ 3.5$ to $\$ 4$ billion in 2014 . This finding in itself is important from a number of perspectives. First, this type of innovation investment is often neglected in empirical studies and policy discussion due to a lack of measurement and analysis and a preoccupation with internal development costs via in-house R\&D. By highlighting the substantial size of such investments for all innovative businesses in Australia, this study draws attention to the significant role and cost of outsourced innovation activities. Second, this finding exposes the need for developing new reliable, meaningful, and comparable data sources that can be analyzed to better understand the different types of innovation investments, the associated risks, potential returns, and capabilities required for innovation success. Third, from a business strategy perspective, the results highlight the need for businesses to maintain the right supplier networks and nurture the capabilities required to source and integrate external expertise, knowledge, technology, and equipment for innovation.

Although the results show that the median level of external investment is highest for businesses in manufacturing, businesses in services still account for $87.3 \%$ of the total amount of external investments. This is because - as is the case in most other developed economies -over two thirds of businesses in Australia are in service sectors. This also explains why the lion's share of external innovation investment (88.3\%) is allocated to purchases of new machinery, equipment, and technology for innovation, as we know from previous research that investment in fixed assets for innovation is relatively more important in services (compared to manufacturing industries) (Brouwer \& Kleinknecht, 1997). In addition, survey results show that the bulk of total external investments in Australia were made by businesses with 200 or more employees, a relevant finding for policies aimed at targeting innovation activity in small firms.

Taken together, the results demonstrate that hidden innovation investments are large enough to warrant wider policy attention and are likely to be sensitive to government policy settings (such as taxation incentives and business support programs). Better information on the patterns of business innovation investment by expenditure type, business size, and industry has the potential to help inform and target economic policies aimed at stimulating business investment and innovation activity. R\&D support policies, for example, may be of little benefit for much innovation activity in the service sectors, given the amount of investment in machinery and equipment that embeds $R \& D$ conducted by suppliers. One implication from this study is that general policies designed to stimulate business investment might benefit from additional conditions tying investment expenditures to innovation activities. Rather than allowing for simple equipment upgrading or refurbishments, non-R\&D investment support policies should favour activities that enhance productivity and innovation capability. One limitation in this study is that the categories of external innovation investment examined are by no means exhaustive. Also, the study does not examine the link between different types of innovation investments, innovation outcomes, and firms performance. Both of these limitations should inform future research.

\section{Acknowledgements}

This project received funding from the Commonwealth Department of Industry, Innovation and Science.

\section{About the Author}

Kieran O'Brien is a Senior Research Fellow at the Australian Innovation Research Centre (AIRC) at the University of Tasmania, Australia. His role involves ongoing management of the AIRC's Tasmanian Innovation Census (TIC) project and related research. Kieran's research interests focus on innovation measurement and innovation activities in the business sector, particularly in low-tech industries where innovation often occurs through a diffusion-adoption process. Related interests include the different modes of innovation, innovation capability and innovation policy as they relate to economic development. Kieran has previously worked in management, research and policy analysis roles in Commonwealth Government agencies including the Australian Bureau of Statistics and the Australian Department of Education, Science and Training. 


\section{Patterns of External Innovation Investment in Australian Businesses}

\section{Kieran O'Brien}

Appendix A. Total external innovation investments by industry

\begin{tabular}{lccccc}
\hline & $\begin{array}{c}\text { Number of } \\
\text { Respondents }\end{array}$ & Total Expenditure & $\begin{array}{c}\text { Median } \\
\text { Expenditure }\end{array}$ \\
\hline Primary resources & 33 & $\mathbf{1 4 . 7 \%}$ & $\$ 195,636,000$ & $11.0 \%$ & $\$ 72,000$ \\
\hline Manufacturing & 16 & $7.1 \%$ & $\$ 30,176,000$ & $1.7 \%$ & $\$ 117,000$ \\
\hline Services & 176 & $78.2 \%$ & $\$ 1,550,295,000$ & $87.3 \%$ & $\$ 21,000$ \\
\hline All firms & $\mathbf{2 2 5}$ & $\mathbf{1 0 0 . 0 \%}$ & $\mathbf{\$ 1 , 7 7 6 , 1 0 7 , 0 0 0}$ & $\mathbf{1 0 0 \%}$ & $\mathbf{\$ 3 3 , 0 0 0}$ \\
\hline
\end{tabular}

Appendix B. Method for calculating total innovation investments for all innovative Australian businesses

Table 2 shows two sets of indicative estimates for total external innovation investments by Australian businesses. The lower level estimate is imputed using the innovation rates reported in the 2013-14 Australian Bureau of Statistics Business Characteristics Survey (ABS, 2014a). Using this method, we apply the innovation rate reported by the Australian Bureau of Statistics to the estimated total number of businesses (ABS, 2014a) to impute the total number of innovative Australian businesses in each size group. The estimated value of total innovation investment for all Australian businesses in each size group is imputed by multiplying the median investment value by size group from the survey (shown in Table 1), by the estimated number of innovative Australian businesses in each size group from the Australian Bureau of Statistics. For all firms across all size groups combined, an estimate is generated by summing the individual estimates for each size group. This provides an estimate of total external innovation investment for all Australian businesses.

For the upper level estimate, the estimated number of innovative Australian businesses is imputed using the innovation rate reported in the survey from this study multiplied by the estimated number of Australian businesses in each size group from the Australian Bureau of Statistics. Because the innovation rate is higher in the survey from this study, this method provides a higher level estimate. These figures are indicative only - they do not incorporate any response bias or population weightings, nor do they feature standard errors. Despite these limitations, they suggest that the value of undetected expenditures on innovation in Australian businesses is likely to be large enough to warrant measurement.

\section{References}

Barrett, P. S., Abbott, C., Sexton, M. G., \& Ruddock, L. 2007. Hidden Innovation in the Construction and Property Sectors. RICS Research Paper Series, 7(20). Manchester, UK: University of Salford.

ABS. 2014a. Cat. 8166.0 - Summary of IT Use and Innovation in Australian Business, 2013-14. Canberra: Australian Bureau of Statistics (ABS).

http://www.abs.gov.au/ausstats/abs@.nsf/mf/8166.0

ABS. 2014b. Cat. 8104.0 - Research and Experimental Development, Businesses, Australia, 2013-14. Canberra: Australian Bureau of Statistics (ABS).

http://www.abs.gov.au/AUSSTATS\%5Cabs@.nsf/0/17EF02A502964 9E2CA257F990030EDFE
ABS. 2015. Cat. 5204.0 - Australian System of National Accounts, 2014-15, Table 5, Gross Value Added by Industry, Series ID A3347198W. Canberra: Australian Bureau of Statistics (ABS). http://www.abs.gov.au/ausstats/abs@.nsf/mf/5204.0

Arundel, A., Bordoy, C., \& Kanerva, M. 2008. Neglected Innovators: How Do Innovative Firms that Do Not Perform R\&D Innovate? Results of an Analysis of the Innobarometer 2007 Survey No. 215. INNO-Metrics Thematic Paper. Maastricht: MERIT.

Arundel, A., \& O'Brien, K. R. 2009. Innovation Metrics for Australia. In Innovation Metrics for Australia: Consolidated Report: 11-133. Canberra: Australian Government, Department of Innovation Industry, Research and Science. 


\section{Patterns of External Innovation Investment in Australian Businesses}

\section{Kieran O'Brien}

Barge-Gil, A., Nieto, M.A., \& Santamaría, L. 2011. Hidden Innovators: The Role of Non-R\&D Activities. Technology Analysis and Strategic Management, 23(4): 415-432.

http://dx.doi.org/10.1080/09537325.2011.558400

Brouwer, E., \& Kleinknecht, A. 1997. Measuring the Unmeasurable: A Country's Non-R\&D Expenditure on Product and Service Innovation. Research Policy, 25(8): 1235-1242.

http://dx.doi.org/10.1016/S0048-7333(96)00902-X

Chesbrough, H. 2003. Open Innovation: The New Imperative for Creating and Profiting from Technology. Boston, MA: Harvard Business School Press.

Damanpour, F., \& Aravind, D. 2012. Managerial Innovation: Conceptions, Processes, and Antecedents. Management and Organization Review, 8(2): 423-454.

http://dx.doi.org/10.1111/j.1740-8784.2011.00233.x

Demirel, P., \& Mazzucato, M. 2012. Innovation and Firm Growth: Is R\&D Worth It? Industry and Innovation, 19(1): 45-62. http://www.jstor.org/stable/2109925

DIIS. 2015. Science, Research and Innovation Budget 2015-2016 Tables. Canberra: Australian Government, Department of Industry, Innovation and Science (DIIS).

http://www.industry.gov.au/innovation/reportsandstudies/Pages/ SRIBudget.aspx

EBRD. 2014. Transition Report 2014: Innovation in Transition. European Bank for Reconstruction and Redevelopment (EBRD).

Gallouj, F., \& Weinstein, O. 1997. Innovation in Services. Research Policy, 26(4-5): 537-556.

http://dx.doi.org/10.1016/S0048-7333(97)00030-9

Godin, B. 2000. A Note on the Survey as an Instrument for Measuring Science and Technology. Montreal: Project on the History and Sociology of S\&T Statistics.

Hansen, P. A., \& Serin, G. 1997. Will Low Technology Products Disappear? The Hidden Innovation Processes in Low Technology Industries. Technological Forecasting and Social Change, 55(2): 179-191. http://dx.doi.org/10.1016/S0040-1625(97)89490-5

Harris, M., \& Halkett, R. 2007. Hidden Innovation: How Innovation Happens in Six 'Low Innovation' Sectors. London: NESTA.

Hervas-Oliver, J. L., Albors-Garrigos, J., \& Gil-Pechuan, I. 2011. Making Sense of Innovation by R\&D and Non-R\&D Innovators in Low Technology Contexts: A Forgotten Lesson for Policymakers. Technovation, 31(9): 427-446.

http://dx.doi.org/10.1016/j.technovation.2011.06.006

Hirsch-Kreinsen, H. 2008. Low-Technology: A Forgotten Sector in Innovation Policy. Journal of Technology Management and Innovation, 3(3): 11-20.

http://dx.doi.org/10.4067/S0718-27242008000100002
Huizingh, E. K. 2011. Open Innovation: State of the Art and Future Perspectives. Technovation, 31(1): 2-9.

http://dx.doi.org/10.1016/j.technovation.2010.10.002

Kirner, E., Kinkel, S., \& Jaeger, A. 2009. Innovation Paths and the Innovation Performance of Low-Technology Firms - An Empirical Analysis of German Industry. Research Policy, 38(3): 447-458. http://dx.doi.org/10.1016/j.respol.2008.10.011

Kleinknecht, A., van Montfort, K., \& Brouwer, E. 2002. The Non-Trivial Choice between Innovation Indicators. Economics of Innovation and New Technology, 11(2): 109-121. http://dx.doi.org/10.1080/10438590210899

Miles, J. 2005. Innovation in Services. In J. Fagerberg, D. Mowery, \& R. Nelson (Eds), The Oxford Handbook of Innovation: 433-458. Oxford: Oxford University Press.

OECD. 2005. Oslo Manual: Guidelines for Collecting and Interpreting Innovation Data (3rd edition). Paris: Organisation for Economic Cooperation and Development (OECD)..

OECD. 2006. Government R\&D Funding and Company Behaviour: Measuring Behavioural Additionality. Paris: Organisation for Economic Cooperation and Development (OECD).

OECD. 2013. OECD Science, Technology and Industry Scoreboard 2013: Innovation for Growth. Paris: Organisation for Economic Cooperation and Development (OECD).

Smith, K., \& Marsh, I. 2007. Wine and Economic Development: Technological and Corporate Change in the Australian Wine Industry. International Journal of Technology and Globalisation, 3(2-3): 224-245. http://dx.doi.org/10.1504/IJTG.2007.014334

Santamaría, L., Nieto, M. J., \& Barge-Gil, A. 2009. Beyond Formal R\&D: Taking Advantage of Other Sources of Innovation in Lowand Medium-Technology Industries. Research Policy, 38(3): 507-517.

http://dx.doi.org/10.1016/j.respol.2008.10.004

Sundbo, J. 1997. Management of Innovation in Services. The Service Industries Journal, 17(3): 432-455.

van de Vrande, V., Vanhaverbeke, W., and Gassmann, O. 2010. Broadening the Scope of Open Innovation: Past Research, Current State and Future Directions. International Journal of Technology Management, 52(3/4): 221-235. http://dx.doi.org/10.1504/IJTM.2010.035974

von Hippel E. 2005. Democratizing Innovation. Cambridge, MA: MIT Press.

von Tunzelmann, N. \& Acha, V. 2005. Innovation in 'Low-Tech' Industries. In J. Fagerberg, D. Mowery, \& R. Nelson (Eds), The Oxford Handbook of Innovation: 407-432. Oxford: Oxford University Press. 